\title{
RESEARCH
}

Open Access

\section{Plasmid profiling of multiple antibiotic- resistant Pseudomonas aeruginosa isolated from soil of the industrial area in Chittagong, Bangladesh}

Asma Talukder ${ }^{1}$, Md. Mijanur Rahman ${ }^{2^{*}} \mathbb{D}$, Mohammed Mehadi Hassan Chowdhury², Tanha Amina Mobashshera ${ }^{3}$ and Nazneen Naher Islam ${ }^{3}$

\begin{abstract}
Background: Multiple antibiotic-resistant (MAR) Pseudomonas aeruginosa ( $P$. aeruginosa) plays a significant role in triggering nosocomial infection in clinical settings. While $P$. aeruginosa isolated from the environment is often regarded as non-pathogenic, the progressive development of antibiotic resistance necessitates exploring the MAR patterns and transposable genetic elements like plasmid in the isolates.

Results: Using ecfX gene-based PCR, 32 P. aeruginosa isolates among 48 soil samples collected from the industrial region have been confirmed. The antibiotic susceptibility pattern of those isolates revealed that $5(15.63 \%)$ of them were resistant to a range of antibiotics, and they were categorized as MAR isolates. Nevertheless, all MAR isolates were found resistant to piperacillin and gentamicin, but none of them to ceftazidime, aztreonam, and ciprofloxacin. Moreover, the isolates were also showed resistance to amikacin (60\%), tobramycin (80\%), netilmicin (80\%), imipenem (60\%), doripenem (40\%), meropenem (60\%), and cefixime (40\%). Furthermore, $60 \%$ of MAR isolates possessed double plasmids of 1000-2000 bp sizes which indicates the distribution of antibiotic resistance genes in MAR P. aeruginosa might be correlated with the presence of those plasmids. The MAR index's high threshold values ( $>0.20$ ) implied that the isolates were from high-risk environmental sites where the presence of numerous antibiotic residues happened.

Conclusions: These findings highlighted the presence of multiple antibiotic resistance in $P$. aeruginosa of the industrial soil and a considerable prospect of transferring antibiotic resistance genes in the microbial community by plasmids. We recommend taking immediate stringent measures to prohibit the unnecessary and overuse of antibiotics in agricultural, industrial, or other purposes.
\end{abstract}

Keywords: Pseudomonas aeruginosa, Multiple antibiotic-resistance, Plasmids, Soil

\footnotetext{
* Correspondence: mijanur@nstu.edu.bd; mijan.cu91@gmail.com

2Department of Microbiology, Noakhali Science and Technology University,

Noakhali 3814, Bangladesh

Full list of author information is available at the end of the article
}

\section{Springer Open}

(c) The Author(s). 2021 Open Access This article is licensed under a Creative Commons Attribution 4.0 International License, which permits use, sharing, adaptation, distribution and reproduction in any medium or format, as long as you give appropriate credit to the original author(s) and the source, provide a link to the Creative Commons licence, and indicate if changes were made. The images or other third party material in this article are included in the article's Creative Commons licence, unless indicated otherwise in a credit line to the material. If material is not included in the article's Creative Commons licence and your intended use is not permitted by statutory regulation or exceeds the permitted use, you will need to obtain permission directly from the copyright holder. To view a copy of this licence, visit http://creativecommons.org/licenses/by/4.0/. 


\section{Background}

Pseudomonas aeruginosa is omnipresent in soil, plants, hospital wastewater, bathrooms, tubs, and bathtub faucet [1]. It has been considered a principal causative agent of hospital-acquired infections worldwide and accounts for around $10 \%$ of its annual incidence. Typical antibiotic regimens against $P$. aeruginosa are progressively getting unsuccessful owing to the emerging drug resistance that eventually poses a perpetual threat to public health [2]. Moreover, it is also a leading cause of ventilatorassociated pneumonia, cystic fibrosis, meningitis, abscess, infections of the cornea, soft tissue and urinary tract, catheter-related infections, and conjunctival erythema [3]. It often induces crippling recurrent lung diseases in cystic fibrosis patients, immunocompromised, and patients undergoing chemotherapy [4]. Furthermore, the Centers for Disease Control and Prevention (CDC) stated that almost 51,000 healthcare-associated $P$. aeruginosa infections arise annually in the USA, in which around $6000(13 \%)$ are triggered by multidrug-resistant (MDR) P. aeruginosa responsible for 400 deaths per annum [5]. National Healthcare Safety Network documented that $P$. aeruginosa is the sixth top etiologic agent causing hospital-acquired infection, and it holds the second position in causing ventilator-associated pneumonia within hospitals of the USA [6].

Soil plays a significant role as a source of nutrients in the environment, works as a shelter for plants and other species, and even serves as a big bioreactor, where pollutant decomposition and nutrient alteration occurs. Moreover, it is also a location where an encounter between local microorganisms and antibiotics happened washed with natural fertilizers and wastewaters into the soil [7]. In the past few decades, soil bacteria have been incrementally antibiotic tolerant even though more stringent antibiotic usage laws exist in medicine and agriculture [4]. The regions most influenced by human usage, where the interaction between clinical pathogenic isolates and environmental isolates happened, and the presence of several antimicrobial selective pressure together, is ideal for exchanging and disseminating resistance genes. It has been reported that the prevalence and distribution of antibiotic-resistant genes are comparatively higher in the antibiotics-producing bacterial community. Consequently, bacteria work as a pool of resistant genes integrated into the broad microbial population $[8,9]$.

$P$. aeruginosa can survive in divergent environments though typically found in low numbers $[10,11]$. Industrial areas, including tanneries, garments, ship breaking, pulp and paper, refineries, food, fertilizer, textile, pharmaceuticals, steel, chemical, and other agro-based industries, are the potent source of environmental pollution as these sites expose their waste byproducts into their surroundings in a known or unknown way [12]. These industrial zones are enriched with different nutrients, including inorganic and organic residues, toxic organic components, and antibiotic-resistant pathogens [13], which pose severe threats to the environment [14]. $P$. aeruginosa has been commonly found in hydrocarbonpolluted areas and could be superior among hydrocarbon reducing bacteria. As a temporary habitat of bacteria, the functions of non-clinical environments remain in dispute $[11,15]$. Although $P$. aeruginosa is recommended for using in bioremediation or plant protection [11], there is a high chance for wide distribution of pathogenic bacteria if it carries virulent genes [16], which will eventually bring adverse effects on public health. Therefore, it is highly demanded to screen the prevalence of antibiotic-resistant $P$. aeruginosa in the soil in the industrial regions. $P$. aeruginosa is also described by inherent multidrug resistance and the capacity to establish high-level (acquired) antibiotic resistance via several processes, including the acquisition of transposable genetic materials, plasmids, and integrons, conclusively crucial for the spread of multidrug resistance in Gram-negative bacteria, particularly in Pseudomonas [17]. Plasmid profiling comes up with a fast and reliable means of identifying bacterial isolates of the same strain and assistance to examine bacterial plasmid content [18]. These plasmids could be the potential carriers of antibiotic-resistant genes among bacteria in the environment. Plasmids can be passed in bacteria within the same or different genera by conjugation and transduction though resistant genes are disseminated by replication $[19,20]$. Moreover, the plasmid transition requirement such as pilli synthesis is typically encoded in the plasmids by genes. Plasmids may also carry genes that code for other functions, such as bacteriocin synthesis, which triggers antibiotic resistance effectively. Hence, $P$. aeruginosa is a leading critical organism to control due to its intrinsic virulence factors and plasmidmediated acquired antibiotic resistance [21, 22].

To understand the contribution of $P$. aeruginosa in disseminating antibiotic resistance in environmental bacteria, we have conducted a cross-sectional study in the industrial area of the Chittagong district in Bangladesh. In this study, we screened and characterized multiple antibiotic-resistant (MAR) P. aeruginosa based on plasmid profiling and calculated the MAR index value to determine the high-risk contamination source.

\section{Methods}

\subsection{Sample collection and isolation of Pseudomonas aeruginosa}

A total of 48 soil samples were collected from eight different locations in the industrial area of Chittagong, Bangladesh, following the simple random sampling 
method from March 2015 to April 2015. The samples (each sample's weight was 500 grams) were taken from $50 \mathrm{~mm}$ underneath the land surface in sterile pots and immediately sent to the laboratory. Serial dilutions of the samples were performed up to $10^{-10}$ in normal saline. Then, $200 \mu \mathrm{L}$ of each dilution was spread to cetrimide agar media (Oxoid, UK) separately and incubated at $37^{\circ} \mathrm{C}$ for $72 \mathrm{~h}$ [9]. All isolates have been purified and freshly sub-cultured on Luria-Bertani (LB) agar media at $37^{\circ} \mathrm{C}$ for $24 \mathrm{~h}$ [23]. Morphological (size, shape, gram reaction) and biochemical $\left(\mathrm{H}_{2} \mathrm{~S}\right.$ generation, reduction of nitrates, and fermentation of various carbohydrates) characteristics were determined [24].

The ecf $X$ gene was detected as a stable genetic marker encoding an ECF (extracytoplasmic function) sigma factor and confined to $P$. aeruginosa from environmental samples; a species-specific PCR-based ecfX gene assay has been performed to validate the detection of $P$. aeruginosa from soil samples [25]. Selected $P$. aeruginosa isolates were then confirmed by ecfX gene-based PCR. Bacterial chromosomal DNA was extracted following the conventional heat-thaw method. The PCR has been done employing a thermal cycler (GeneAmpR PCRSystem 9700, Applied Biosystems) following the protocol delineated by Talukder et al. [26]. The forward and reverse primers had the following sequences- Primer 1 (ECF5), 5'-AAGCGTTCGTCCTGCACAA-3', and Primer 2 (ECF2), 5'-TCATCCTTCGCCTCCCTG-3', respectively $[25,26]$.

\subsection{Antimicrobial susceptibility testing}

Antimicrobial susceptibility testing has been performed according to the Kirby-Bauer disc diffusion method on Mueller-Hinton agar (Oxoid, UK) following the Clinical Laboratory Standards Institute guidelines [9, 27]. The standard antibiotic discs of piperacillin (PIP) $(100 \mu \mathrm{g})$, gentamicin (GEN) $(10 \mu \mathrm{g})$, amikacin (AMK) $(30 \mu \mathrm{g})$, tobramycin (TOB) $(10 \mu \mathrm{g})$, netilmicin (NET) $(30 \mu \mathrm{g})$, imipenem (IPM) $(10 \mu \mathrm{g})$, doripenem (DOR) $(10 \mu \mathrm{g})$, meropenem (MEM) $(10 \mu \mathrm{g})$, ceftazidime (CAZ) $(30 \mu \mathrm{g})$, cefixime (CFM) $(5 \mu \mathrm{g})$, aztreonam (ATM) $(30 \mu \mathrm{g})$, and ciprofloxacin (CIP) $(5 \mu \mathrm{g})$ were used. P. aeruginosa were designated as susceptible (S), intermediate (I), or resistant (R) according to CLSI guidelines [27, 28].

\subsection{Multiple antibiotic resistance (MAR) indexing}

$P$. aeruginosa were regarded as multiple antibioticresistant (MAR) if any of them showed resistance to two or more antimicrobial drugs [9]. MAR index values were calculated following the procedure illustrated by Osundiya et al. [29]. MAR index for a single isolate was calculated as the following formula: "Number of antibiotics to which isolate is resistant (a)/Total number of antibiotics against which isolate was tested (b)" [29].

\subsection{Plasmid profiling of multiple antibiotic-resistant $P$. aeruginosa}

Plasmid DNA extraction was carried out employing the standard alkaline lysis protocol delineated by Sambrook et al. [30]. Three complex solutions such as solution-I (50 mM glucose; $10 \mathrm{mM}$ EDTA, $\mathrm{pH}$ 8.0; $2 \mu \mathrm{M}$ Tris- $\mathrm{HCl}$, $\mathrm{pH}$ 8.0), solution-II (0.2 N NaOH; $1 \%$ SDS), and solution-III ( $5 \mathrm{M}$ potassium acetate; $5 \mathrm{M}$ glacial acetic acid) have been prepared for this purpose. Two milliliters of freshly cultured $P$. aeruginosa was centrifuged for $10 \mathrm{~min}$ at 10,000 rpm; then, the pellet was suspended in solution-I. The solution-II has been applied to that mixture for lysing the bacterial cells. Then, solution-III was added to the mix and recentrifuged to precipitate genomic DNA. The supernatant was collected and treated with phenol-chloroform solution, and the upper layer of the solution was separated into another Eppendorf tube, then RNAse $(20 \mu \mathrm{L} / \mathrm{mL})$ added to it. The mix was then centrifuged at $4{ }^{\circ} \mathrm{C}$ for $10 \mathrm{~min}$ at $10,000 \mathrm{rpm}$. The pellet was taken and washed with ethanol twice. Then, the pellet has been mixed in $50 \mu \mathrm{L}$ TE buffer ( $\mathrm{pH}$ 8.0). Finally, the plasmid DNA has been visualized performing 1.5\% agarose gel electrophoresis using ethidium bromide as a staining agent under UV light [12].

\section{Results}

A total of forty-eight soil samples have been collected from different locations of the industrial area in Chittagong, and $32 \mathrm{P}$. aeruginosa isolates were identified. Antibiotic susceptibility testing of the isolates revealed that $5(15.63 \%)$ of them were multiple antibiotic-resistant (MAR) (Table S1). The MAR $P$. aeruginosa isolates P1, P7, P8, P13, and P22 (Fig. 1) were found resistant to six, eight, seven, and six antibiotics, respectively (Table 1 ). This study revealed that all MAR P. aeruginosa (5, 100\%) were resistant to piperacillin which belongs to the penicillin group antibiotics. In the aminoglycosides group, $100 \%$ of MAR isolates found resistant to gentamicin, $80 \%$ to tobramycin and netilmicin, and $60 \%$ to amikacin. Nearly half of the MAR isolates were resistant to carbapenems, where $60 \%$ to imipenem and meropenem and $40 \%$ to doripenem. Moreover, against third-generation cephalosporins, $40 \%$ of MAR isolates were resistant to cefixime and none to ceftazidime. In contrast, all MAR isolates were found sensitive to aztreonam (monobactams group) and ciprofloxacin (fluoroquinolones group) in this study (Fig. 2, Table 1). Nonetheless, though our primary focus on the antibiotic resistance of MAR isolates, it is worth to be mentioned that all the $32 \mathrm{P}$. aeruginosa were sensitive to aztreonam and ciprofloxacin. Furthermore, the MAR index of the isolates revealed that all $P$. aeruginosa were found with greater than 


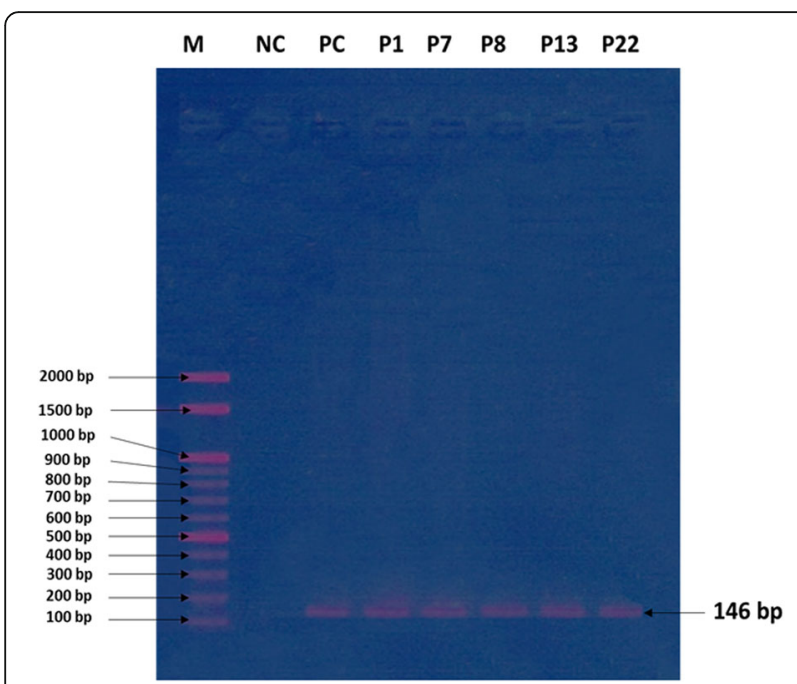

Fig. 1 PCR amplification of ecfx gene (146 bp) of $P$. aeruginosa isolates (lane M denoted size marker of 100-2000 bp, lanes NC and PC denoted negative and positive control respectively, lanes P1, P7, P8, P13, and P22 were $P$. aeruginosa isolates)

0.20 index values (0.33 to 0.67$)$ which implied that they were from high-risk environments (Table 1). In addition, the plasmid profiling of the MAR P. aeruginosa showed that $60 \%$ of them possessed double plasmids of 1000-2000 bp sizes, and rest of the isolates did not have any plasmids (Fig. 3).

\section{Discussion}

A study by Kaszab et al. [31] reported that soil-derived $P$. aeruginosa showed high resistance against two distinct groups of antibiotics at minimum, particularly wide spectrum penicillins, third-generation cephalosporins, carbapenems, and aminoglycosides. These findings supported our observations and indicated a strong and alarming antibiotic resistance profile of environmental isolates of $P$. aeruginosa, which could lead to a massive distribution of antibiotic-resistant isolates in a broad microbial community. Besides this, Deredjian et al. [32] found that $14 \%$ of the $P$. aeruginosa were resistant up to five antibiotics (gentamicin, ticarcillin, tobramycin, imipenem, clavulanic acid, and ciprofloxacin), whereas, in contrast, none of the MAR isolates in this study showed resistance against ciprofloxacin and ceftazidime. Likewise, our findings, a contemporary study [11], stated that the imipenem-resistant $P$. aeruginosa were exclusively isolated from hydrocarbon-contaminated samples. The environmental stress from metals and hydrocarbons could make antibiotic-resistant bacteria more prevalent in polluted soils. There is a crucial little-known association between contaminated soil and antibiotic resistance. It is an eminent need to clarify the danger of horizontal gene transfer among clinical pathogens, soil microorganisms, and commensal bacteria; and a better understanding of environmental triggers for gene transfer [33]. Unlike our findings, a similar study by PitondoSilva et al. [9] reported that most $P$. aeruginosa isolated from soil were resistant to aztreonam and ticarcillin significantly and resistant isolates possessed plasmids and class 1 integron.

In the USA, it has been estimated that almost 26,000 $P$. aeruginosa isolates were recovered annually. Among them, around $19.3 \%$ were resistant or intermediately susceptible to one carbapenem antibiotics at a minimum level. In contrast, roughly $14 \%$ of them found as multidrug-resistant exhibited extreme resistance facilitated by several antibiotic resistance mechanisms such as modification of the target sites, beta-lactamase production, porin alterations, and antibiotic efflux [34]. Beta-lactamase enzymes production is considered an essential mechanism of resistance commonly used by $P$. aeruginosa [35], even though it can demonstrate tolerance to non-beta-lactam antibiotics via the modification of the antibiotic target site. However, fluoroquinolones and aminoglycosides are two antibiotic groups affected by the resistance process $[34,36]$.

The MAR index of bacteria is commonly considered to determine the sampling sites targeting high-risk contamination sources $[37,38]$. It is a practical, costeffective, and justifiable technique of tracking the source of multiple antibiotic-resistant bacteria by "calculating the ratio of the number of resistant antibiotics to which the organism is resistant to, and the total number of antibiotics to which the organism is exposed" [39]. The multiple antibiotic resistance (MAR) indexing values of isolated $P$. aeruginosa were recorded from 0.33 to 0.67 . The value of the MAR index above 0.2 admitted the

Table 1 Multiple antibiotic resistance (MAR) pattern of Pseudomonas aeruginosa isolates with MAR index values

\begin{tabular}{lllll}
\hline Sample ID & Isolate ID & Resistance pattern & Number of resistant antibiotics (a) & MAR index (a/b) \\
\hline CIS-3 & P1 & PIP, GEN, AMK, NET, IPM, MEM & 6 & 0.5 \\
& P7 & PIP, GEN, AMK, TOB, NET, IPM, MEM, CFM & 8 & 0.67 \\
CIS-18 & P8 & PIP, GEN, AMK, TOB, NET, DOR, CFM & 7 & 0.58 \\
& P13 & PIP, GEN, TOB, NET, DOR, MEM & 6 & 0.5 \\
CIS-31 & P22 & PIP, GEN, TOB, IPM & 4 & 0.33
\end{tabular}

$a$, number of antibiotics to which isolates are resistant; $b=12$, total number of antibiotics against which isolates were tested 


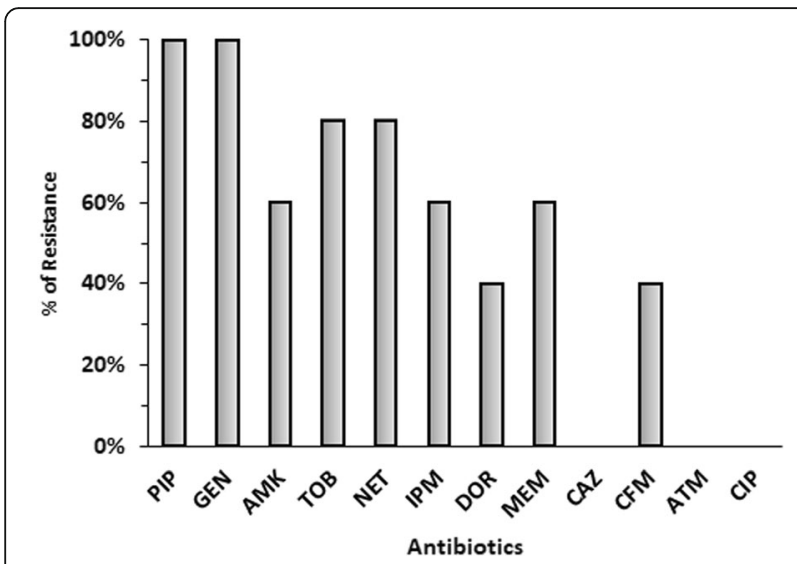

Fig. 2 Antibiotic resistance of MAR P. aeruginosa isolates against commonly used antibiotics

survival ability of the isolates in a highly polluted atmosphere, and this higher contamination could result from an abundance of multiple antibiotic residues in sites [30, 40]. Resistance to multiple antibiotics in environmental bacteria without direct selection pressure could be implicated for several instances, such as the introduction of antibiotics in the environment and spreading resistance gene sequences. Some considerable ways that contribute to disseminating antibiotics and resistant strains of $P$. aeruginosa could be patients, public antibiotic usage, the flow of waste and sewage to the environment, employing bacteria in bioremediation purposes, use of antibiotics in agriculture, and certain actinomycetes in soil. In the coming days, as we see already, the multiple antibiotic-

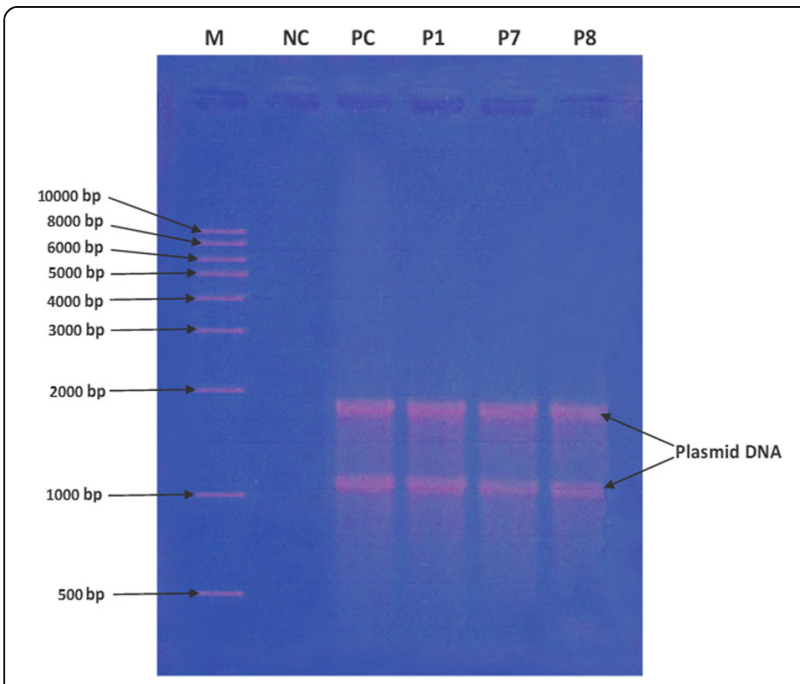

Fig. 3 Plasmid profiles of the multiple antibiotic-resistant (MAR) $P$. aeruginosa isolates (lane M denoted size marker of 500-10,000 bp, lanes NC and PC denoted negative and positive control, respectively, lanes P1, P7, and P8 were $P$. aeruginosa isolates have two plasmids of sizes between 1000 and 2000 bp) resistant $P$. aeruginosa would be increased alarmingly in both the hospital settings and in the environment [41].

Plasmid profiling of the $P$. aeruginosa showed that $60 \%$ of the MAR isolates in this study had double plasmids of 1000-2000 bp sizes. The findings of Akingbade et al. [18] showed that eight (36.4\%) multidrug-resistant $P$. aeruginosa isolated from human wound specimens possessed plasmid, wherein two (25\%) of them had double, and six (75\%) of them contained a single plasmid. All plasmids harboring isolates showed resistance to amoxicillin, ampicillin, erythromycin, tetracycline, cotrimoxazole, and cloxacillin [18]. Likewise, our findings, Odumosu et al. [42] reported that the $P$. aeruginosa isolated from humans, animals, and plants had versatile plasmid profiles with copies of 1 to 5 and size ranges < $1000 \mathrm{bp}$ to $\geq 23,000 \mathrm{bp}$. Furthermore, a study has shown that $P$. aeruginosa lost their resistance markers after losing their plasmids [43]. Thus, it can be construed that a plasmid possibly facilitated the antibiotic resistance of those bacteria. Mobile genetic materials like plasmids are responsible for disseminating resistance genes among the bacterial community and act as a transporter for other resistance mechanisms [42]. In Gram-negative bacteria, plasmids are harboring antibiotic-resistant genes that facilitate numerous antibiotics resistance [44]. These self-governing DNA molecules can transmit between cells and turn on a portion of the chromosome via high-recurrence recombination [20]. Analysis of plasmids and their functions provide essential insight into antibiotic resistance. Genotyping and other molecular characterization of plasmids could help to determine the reasons for occurring antibiotic-resistant genes. Plasmids are significantly implicated in horizontal gene transfer in intimate bacterial families disseminating antibioticresistant genes in the environment. Therefore, plasmid profiling could assist in the routine surveillance of outbreaks and tracking antibiotics resistance [22].

\section{Conclusion}

The occurrence of multiple antibiotic-resistant $P$. aeruginosa with harboring plasmids in environmental samples such as soil from the industrial area signifies the possibility of widespread dissemination of antibiotic resistance in microbial communities through $P$. aeruginosa. The obtained data in this study is not only alarming but also scary for the public health sector. Effective control measures are highly recommended to reduce contamination in environmental sites. The spread of antibioticresistant pathogens must be controlled in constructive and realistic ways. Nonetheless, to figure out the whole scenario of the antibiotic resistance pattern of $P$. aeruginosa and its possible consequences in both environment and health sector, region-specific, large-scale, and more comprehensive studies are needed. 


\section{Supplementary Information}

The online version contains supplementary material available at https://doi. org/10.1186/s43088-021-00131-w.

Additional file 1: Table S1. Antibiotic susceptibility test results of all 32 Pseudomonas aeruginosa isolates.

\section{Acknowledgements}

Authors acknowledge all kinds of lab and logistics support provided by the Department of Genetic Engineering and Biotechnology of the University of Chittagong, Bangladesh.

\section{Authors' contributions}

AT and NNI designed the study. AT and TAM have carried out the collection of soil samples and laboratory research. MMR and AT have done the data analysis and prepared the draft manuscript. NNI, MMHC, and MMR edited and critically reviewed the manuscript. The authors have read and approved the final manuscript.

\section{Funding}

None

\section{Availability of data and materials}

Not applicable

\section{Declarations}

Ethics approval and consent to participate

Not applicable

\section{Consent for publication}

Not applicable

\section{Competing interests}

The authors declare that they have no competing interests.

\section{Author details}

'Department of Biotechnology and Genetic Engineering, Noakhali Science and Technology University, Noakhali 3814, Bangladesh. ${ }^{2}$ Department of Microbiology, Noakhali Science and Technology University, Noakhali 3814, Bangladesh. ${ }^{3}$ Department of Genetic Engineering and Biotechnology, University of Chittagong, Chattogram 4331, Bangladesh.

Received: 4 May 2021 Accepted: 17 July 2021

Published online: 03 August 2021

\section{References}

1. Bédard E, Prévost M, Déziel E (2016) Pseudomonas aeruginosa in premise plumbing of large buildings. Microbiologyopen 5(6):937-956. https://doi. org/10.1002/mbo3.391

2. Debnath T, Bhowmik S, Islam T, Chowdhury MM (2018) Presence of multidrug-resistant bacteria on mobile phones of healthcare workers accelerates the spread of nosocomial infection and regarded as a threat to public health in Bangladesh. J Microsc Ultrastruct 6:165

3. Ramírez-Estrada S, Borgatta B, Rello J (2016) Pseudomonas aeruginosa ventilator-associated pneumonia management. Infect Drug Resist 9:7

4. Kumar M, Jaiswal S, Sodhi KK, Shree P, Singh DK, Agrawal PK, Shukla P (2019) Antibiotics bioremediation: perspectives on its ecotoxicity and resistance. Environ Int 124:448-461. https://doi.org/10.1016/j.envint.2018.12. 065

5. Chatterjee M, Anju CP, Biswas L, Kumar VA, Mohan CG, Biswas R (2016) Antibiotic resistance in Pseudomonas aeruginosa and alternative therapeutic options. Int J Med Microbiol 306(1):48-58. https://doi.org/10.1016/j.jmmm.201 5.11 .004

6. Weiner LM, Webb AK, Limbago B, Dudeck MA, Patel J, Kallen AJ, Edwards JR, Sievert DM (2016) Antimicrobial-resistant pathogens associated with healthcare-associated infections: summary of data reported to the National Healthcare Safety Network at the Centers for Disease Control and Prevention, 2011-2014. Infect Control Hosp Epidemiol 37(11):1288-1301. https://doi.org/10.1017/ice.2016.174
7. Cytryn E, Markiewicz Z, Popowska M (2017) Antibiotics and antibiotics resistance genes dissemination in soils. In: In Antibiotics and antibiotics resistance genes in soils. Springer, Cham, pp 151-190

8. Arenas-Lago D, Vega FA, Silva LF, Andrade ML (2013) Soil interaction and fractionation of added cadmium in some Galician soils. Microchem J 110: 681-690. https://doi.org/10.1016/j.microc.2013.08.003

9. Pitondo-Silva A, Martins W, Fernandes AF, Stehling EG (2014) High level of resistance to Aztreonam and Ticarcillin in Pseudomonas aeruginosa isolated from soil of different crops in Brazil. Sci Total Environ 473:155-158

10. Chatterjee P, Davis E, Yu F, James S, Wildschutte JH, Wiegmann DD, Sherman DH, McKay RM, LiPuma JJ, Wildschutte H (2017) Environmental pseudomonads inhibit cystic fibrosis patient-derived Pseudomonas aeruginosa. Appl Environ Microbiol 83:e02701-e02716

11. Kaszab E, Radó J, Kriszt B, Pászti J, Lesinszki V, Szabó Á, Tóth G, Khaledi A, Szoboszlay S (2019) Groundwater, soil and compost, as possible sources of virulent and antibiotic-resistant Pseudomonas aeruginosa. Int J Environ Heal 18:1-3

12. Naraian R, Ram S, Kaistha SD, Srivastava J (2012) Occurrence of plasmid linked multiple drug resistance in bacterial isolates of tannery effluent. Cell Mol Biol 58(1):134-141

13. Srinath $\mathrm{T}$, Khare S, Ramteke PW (2001) Isolation of hexavalent chromiumreducing Cr-tolerant facultative anaerobes from tannery effluent. J Gen Appl Microbiol 47:307-312 Goyal N, Jain SC, Banerjee UC (2003) Comparative studies on the microbial adsorption of heavy metals. Adv Environ Res 7: 311-319

14. Goyal N, Jain SC, Banerjee UC (2003) Comparative studies on the microbial adsorption of heavy metals. Adv Environ Res 7(2):311-319. https://doi.org/1 0.1016/S1093-0191(02)00004-7

15. Deredjian A, Colinon C, Hien E, Brothier E, Youenou B, Cournoyer B, Dequiedt S, Hartmann A, Jolivet C, Houot S, Ranjard L (2014) Low occurrence of Pseudomonas aeruginosa in agricultural soils with and without organic amendment. Front Cell Infect Mi 4:53

16. Jose D, Mohandas A, Singh IB (2018) A non-pathogenic environmental isolate of Pseudomonas aeruginosa MCCB 123 with biotechnological potential. Int J Curr Microbiol App Sci. 7(1):3060-3071. https://doi.org/10.2 0546/ijcmas.2018.701.363

17. Poole K, Srikumar R (2001) Multidrug efflux in Pseudomonas aeruginosa components, mechanisms and clinical significance. Curr Top Med Chem 1(1):59-71. https://doi.org/10.2174/1568026013395605

18. Akingbade OA, Balogun SA, Ojo DA, Afolabi RO, Motayo BO, Okerentugba PO, Okonko IO (2012) Plasmid profile analysis of multidrug resistant Pseudomonas aeruginosa isolated from wound infections in South West, Nigeria. World Appl Sci I 20:766-765

19. Livermore DM (2002) Multiple mechanisms of antimicrobial resistance in Pseudomonas aeruginosa: our worst nightmare? Clin Infect Dis 34(5):634640. https://doi.org/10.1086/338782

20. Rozwandowicz M, Brouwer MS, Fischer J, Wagenaar JA, Gonzalez-Zorn B, Guerra B, Mevius DJ, Hordijk J (2018) Plasmids carrying antimicrobial resistance genes in Enterobacteriaceae. J Antimicrob Chemother 73:11211137

21. Shahid M, Malik A (2004) Plasmid mediated amikacin resistance in clinical isolates of Pseudomonas aeruginosa. Indian J Med Microbiol 22(3):182-184. https://doi.org/10.1016/S0255-0857(21)02833-4

22. Shrestha UT, Shrestha S, Adhikari N, Rijal KR, Shrestha B, Adhikari B, Banjara MR, Ghimire P (2020) Plasmid profiling and occurrence of $\beta$-lactamase enzymes in multidrug-resistant uropathogenic Escherichia coli in Kathmandu, Nepal. Infect Drug Resist 13:1905-1917. https://doi.org/10.2147/ IDR.S250591

23. Mukherjee K, Tribedi P, Chowdhury A, Ray T, Joardar A, Giri S, Sil AK (2011) Isolation of a Pseudomonas aeruginosa strain from soil that can degrade polyurethane diol. Biodegradation 22(2):377-388. https://doi.org/10.1007/s1 0532-010-9409-1

24. Buchanan RE, Gibbons NE (1974) Bergey's manual of determinative bacteriology. The Williams \& Wilkins Company, Baltimore

25. Colinon C, Deredjian A, Hien E, Brothier E, Bouziri L, Cournoyer B, Hartman A, Henry S, Jolivet C, Ranjard L, Nazaret S (2013) Detection and enumeration of Pseudomonas aeruginosa in soil and manure assessed by an ecfX qPCR assay. J Appl Microbiol 114(6):1734-1749. https://doi.org/10.1111/jam.12189

26. Talukder A, Mobashshera TA, Ahmed IU, Islam NN (2018) Bacteriological and ecfX-gene specific PCR based identification of Pseudomonas aeruginosa isolated from Chittagong industrial area and characterization of its 
extracellular amylase. Jahangirnagar Univ J Biol Sci 7(2):99-114. https://doi. org/10.3329/jujbs.v7i2.40751

27. Clinical and Laboratory Standards Institute (2018) Performance standards for antimicrobial discs susceptibility tests. Approved standard M02, 13th edn. Clinical and Laboratory Standards Institute, Wayne

28. Hudzicki J (2016) Kirby-Bauer disk diffusion susceptibility test protocol. American Society for Microbiology, Washington DC

29. Osundiya OO, Oladele RO, Oduyebo OO (2013) Multiple antibiotic resistance (MAR) indices of Pseudomonas and Klebsiella species isolates in Lagos University Teaching Hospital. African J Clin Exp Microbiol 14:164-168

30. Sambrook J, Fritsch EF, Maniatis T (1989) Molecular cloning: a laboratory manual, 2nd edn. Cold Spring Harbor Laboratory Press, Cold Spring Harbor

31. Kaszab E, Szoboszlay S, Dobolyi C, Háhn J, Pék N, Kriszt B (2011) Antibiotic resistance profiles and virulence markers of Pseudomonas aeruginosa strains isolated from composts. Bioresour Technol 102(2):1543-1548. https://doi. org/10.1016/j.biortech.2010.08.027

32. Deredjian A, Colinon C, Brothier E, Favre-Bonté S, Cournoyer B, Nazaret S (2011) Antibiotic and metal resistance among hospital and outdoor strains of Pseudomonas aeruginosa. Res Microbiol 162(7):689-700. https://doi.org/1 0.1016/j.resmic.2011.06.007

33. Cunningham CJ, Kuyukina MS, Ivshina IB, Konev Al, Peshkur TA, Knapp CW (2020) Potential risks of antibiotic resistant bacteria and genes in bioremediation of petroleum hydrocarbon contaminated soils. Environ Sci: Process Impacts 22(5):1110-1124. https://doi.org/10.1039/C9EM00606K

34. Strateva T, Yordanov D (2009) Pseudomonas aeruginosa-a phenomenon of bacterial resistance. J Med Microbiol 58(9):1133-1148. https://doi.org/10.1 099/jmm.0.009142-0

35. J Wolter $D, D$ Lister $P$ (2013) Mechanisms of $\beta$-lactam resistance among Pseudomonas aeruginosa. Curr Pharml Des 19(2):209-222. https://doi.org/1 $0.2174 / 138161213804070311$

36. Nguyen L, Garcia J, Gruenberg K, MacDougall C (2018) Multidrug-resistant Pseudomonas infections: hard to treat, but hope on the horizon? Curr Infect Dis Rep 20(8):23. https://doi.org/10.1007/s11908-018-0629-6

37. Eduardo-Correia B, Morales-Filloy $H$, Abad JP Bacteria from the multicontaminated tinto river estuary (SW, Spain) show high multi-resistance to antibiotics and point to Paenibacillus spp. as antibiotic-resistancedissemination players. Front Microbiol 10:3071

38. Jara D, Bello-Toledo H, Domínguez M, Cigarroa C, Fernández P, Vergara L, Quezada-Aguiluz M, Opazo-Capurro A, Lima CA, González-Rocha G (2020) Antibiotic resistance in bacterial isolates from freshwater samples in Fildes Peninsula, King George Island, Antarctica. Sci Rep 10:1-8

39. Davis R, Brown PD Multiple antibiotic resistance index, fitness and virulence potential in respiratory Pseudomonas aeruginosa from Jamaica. J Med Microbiol 65:261-271

40. Rahman MM, Devnath P, Jahan R, Talukder A (2021) Detection of multiple antibiotic-resistant bacteria from the hospital and non-hospital wastewater sources of a small town in Noakhali, Bangladesh. J App Biol Biotech 9:59-65

41. Kaszab E, Kriszt B, Atzél B, Szabó G, Szabó I, Harkai P, Szoboszlay S (2010) The occurrence of multidrug-resistant Pseudomonas aeruginosa on hydrocarbon-contaminated sites. Microbial ecology 59(1):37-45. https://doi. org/10.1007/s00248-009-9551-7

42. Odumosu BT, Ajetunmobi O, Dada-Adegbola H, Odutayo I (2016) Antibiotic susceptibility pattern and analysis of plasmid profiles of Pseudomonas aeruginosa from human, animal and plant sources. SpringerPlus 5:1-7

43. Beige F, Salehi MB, Bahador N, Mobasherzadeh S (2015) Plasmid mediated antibiotic resistance in isolated bacteria from burned patients. Jundishapur J Microbiol:8. https://doi.org/10.5812/jjm.13567

44. Munita JM, Arias CA (2016) Mechanisms of antibiotic resistance. Virulence Mech Bacterial Pathog 22:481-511. https://doi.org/10.1128/9781555819286. ch17

\section{Publisher's Note}

Springer Nature remains neutral with regard to jurisdictional claims in published maps and institutional affiliations.

\section{Submit your manuscript to a SpringerOpen ${ }^{\circ}$ journal and benefit from:}

- Convenient online submission

- Rigorous peer review

- Open access: articles freely available online

- High visibility within the field

- Retaining the copyright to your article

Submit your next manuscript at $\boldsymbol{\nabla}$ springeropen.com 